\title{
THE ACM'S 16TH NORTH AMERICAN COMPUTER-CHESS CHAMPIONSHIP
}

\section{To be held in Denver, Colorado October 13 to October 15, 1985}

The Association for Computing Machinery will host the 16th North American Computer-Chess Championship at its ACM'85 Conference in Denver, Colorado on October 13-15, 1985. A four-round Swiss-system tournament is planned for approximately twelve to sixteen of the best programs in the world.

CRAY BLITZ (Robert Hyatt, Burt Gower and Harry Nelson), current world champion and winner of ACM's 1984 tournament, is expected to defend its title using a 16-processor Cray computer. BELLE (Ken Thompson, Joe Condon), former world champion, will be out to regain her title as will NUCHESS (David Slate, William Blanchard), a descendant of CHESS 4.6, world champion during 1977-1980. A number of participants will have ratings at or very near the Master Level. BELLE was awarded the Master's title by the United States Chess Federation in 1983.

A special Turing Test is planned on Monday afternoon, October 13th. In the test, a leading human player will play a simultaneous match against elght opponents, some of them humans and some computers. The audience will not see the opponents but will be asked to guess which are humans and which are computers.

A panel discussion entitled "Chess programs: from basement to marketplace" w11l be held October $14 \mathrm{th}$.

Mike Valvo, one of America's leading blindfold chess-players, will serve as tournament director.

For more information, please write Monty Newborn, School of Computer Science, McGill University, 805 Sherbrooke Street West, Montreal, Quebec, CANADA H3A 2K6. For an application to participate, please write Ken Thompson, Room 2C-519, Bell Laboratories, Murray Hill, New Jersey 07974. Individuals with programs which have not participated in past tournaments are encouraged to apply. 